\title{
Serbian Citizens' Awareness of Consumer Rights of Tourists in the EU
}

\author{
Ivana BlešićA, Tatjana Pivac ${ }^{A}$, Janko Veselinović ${ }^{B}$, Sava Janićević ${ }^{A}$ \\ Received: January 08, 2019 | Revised: March 28, 2019 | Accepted: April 22, 2019 \\ DOI: $10.5937 / g p 23-20129$
}

\begin{abstract}
This paper analyses the protection of consumers of tourism services in EU law and consumer awareness in this domain in Serbia as a country currently negotiating accession to the EU. Consumer rights in EU tourism are defined by directives and regulations. This paper shall separately analyse two directives and one regulation that directly pertain to the protection of consumers of tourism services. Most legal sources are the codification of business practices of tourist organizations within the EU, but a part of mandatory provisions is the result of the need to protect consumers of tourism services in the domains of tourism in which they are most exposed to violation of their rights. For the needs of this paper, the survey was carried out on the territory of the Republic of Serbia, for the purpose of obtaining information on citizens' awareness of the rights of consumers of tourism services in EU countries. The main aim of this study is to determine how well informed the citizens of Serbia are regarding consumer rights in tourism and legislation that governs those rights.
\end{abstract}

Keywords: law; tourism; consumer protection; EU; Serbia

\section{Introduction}

Tourism and travel sector account for $10.4 \%$ of the global GDP and 313 million jobs, i.e. 9.9\% of total employment in 2017. Tourism is the third important sector of the economy and a source of growth in the European Union and makes an important contribution to the EU's gross national product and to employment. With a huge cultural heritage and diversity Europe continues to stand as the most visited region, welcoming half of the world's international tourist arrivals. Within Europe, the 28 countries of the EU account for the bulk of the region's international arrivals, some $81 \%$ of Europe's total and $40 \%$ of the world's figure. Tourism contributes $10 \%$ to European Union GDP and creates jobs for 26 million people - through its direct, indirect and induced effects in the economy in special for young people, women and people from a migrant background. The European Union welcomed over 500 million international tourist arrivals in 2016, accounting for $40 \%$ of the world's total. International tourism receipts reached euro 342 billion, representing $31 \%$ of worldwide tourism earnings. On average, every inhabitant of Europe earned euro 445 in 2016 from international tourism, well above the world average of euro 151 per capita (UNWTO, 2018). This makes tourism one of the most resilient sectors of the EU economy. To ensure confidence in the high quality of travel services sold anywhere in the EU market, EU law protects travellers' rights, particularly in relation to package holidays (European Commision, 2013).

The tourism in Serbia is booming. This country is seeing not only a revival in domestic tourism, but also an increase in the influx of foreign tourists. In

\footnotetext{
A University of Novi Sad, Faculty of Sciences, Department of Geography, Tourism and Hotel Management, Novi Sad, Serbia, e-mails: ivana.blesic@dgt.uns.ac.rs; tatjana.pivac@dgt.uns.ac.rs; sava.janicevic@dgt.uns.ac.rs

B University of Novi Sad, Faculty of Agriculture, Novi Sad, Serbia, e-mail: veselinovic.janko@gmail.com

* Corresponding author: Tatjana Pivac; e-mail: tatjana.pivac@dgt.uns.ac.rs; phone: +381641759344; fax: +38121459969
} 
the past five years, the number of foreign tourists has increased by $65 \%$ and the number of overnight stays and foreign exchange earnings by $56 \%$. Since 2013,126 new hotels have been opened (Internet 1). Also, number of domestic tourists traveling abroad is increasing. In 2017 it amounted 843.397 (growth of approximately $11 \%$ compare with 2016.). Domestic tourists mostly travel to Greece, Montenegro, Turkey, Bulgaria and Italy (SORS, 2018).

Table 1. Key facts of Serbian travel and tourism contributions in 2017.

\begin{tabular}{|l|l|}
\hline Contibutions & Facts \\
\hline $\begin{array}{l}\text { GDP: } \\
\text { direct contribution }\end{array}$ & $\begin{array}{l}\text { USD } 906.1 \mathrm{mn} \text { or } 2.3 \% \\
\text { of total GDP in } 2017\end{array}$ \\
\hline $\begin{array}{l}\text { GDP: } \\
\text { total contribution }\end{array}$ & $\begin{array}{l}\text { USD } 2,606.8 \mathrm{mn} \text { or } 6.7 \% \\
\text { of GDP in } 2017\end{array}$ \\
\hline $\begin{array}{l}\text { Employment: } \\
\text { direct contribution }\end{array}$ & $\begin{array}{l}37,000 \text { jobs or } 1.9 \% \\
\text { of total employment }\end{array}$ \\
\hline $\begin{array}{l}\text { Employment: } \\
\text { total contribution }\end{array}$ & $\begin{array}{l}96,500 \text { jobs or } 4.9 \% \\
\text { of total employment }\end{array}$ \\
\hline Visitor exports & $\begin{array}{l}\text { USD } 1,476.3 \mathrm{mn} \text { or } 7.1 \% \\
\text { of total exports in } 2017\end{array}$ \\
\hline Investment & $\begin{array}{l}\text { USD } 299.3 \mathrm{mn} \text { or } 4.1 \% \\
\text { of total investment }\end{array}$ \\
\hline
\end{tabular}

Sources: World Travel \& Tourism Council 2018

Tourism as one of the fundamental and inherent human rights is inseparable from his essence and there has been emphasis for people to enjoy it. The international documents and organizations also have recognized it as a right for humans and countries need to recognize it as their own domestic laws and regulations formulated to provide its implementation (Gharibeh, 2011).

On the very establishment of the EU, the tourism domain was not part of a joint policy, nor was there an emphasis that domestic legislations needed to be harmonized in this domain. The first document in this domain was a request of the European Parliament to the Commission and the Council to take actions in promoting tourism as part of Union's global policy. In the adopted resolution, the European Parliament specified two main goals: liberalization of tourism services and protection of tourists as consumers. The subsequent act was the Council Resolution from 1984 (Council Resolution, 1984) in which the Commission is called to formulate proposals. Based on this request, the Commission proposed 'Tourism Policy of the Union', which was transformed into the programme 'Activities of the Union in the Domain of Tourism'. None of these acts included tourism under the purview of the Union. The turning point may have been the decision of the Council to declare the year 1990 as the 'European Year of Tourism'. This decision aimed to promote tourism within the EU, so that EU citizens could get to know the neighbouring countries, their customs and cultures (Živković, 2013).

The following regulations directly pertain to consumers in the tourism domain:

1. Council Directive no. 90/314/EEC of 13 June 1990 on package travel, package holidays and package tours (Council Directive 90/314/EEC, L 158/59). This oldest EU DIRECTIVE shall be replaced on o1 January 2018 with a new Directive (EU) 2015/2302 of the European Parliament and of the Council of 25 November 2015 on package travel and linked travel arrangements, amending Regulation (EC) No 2006/2004 and Directive 2011/83/EU of the European Parliament and of the Council and repealing Council Directive 90/314/EEC (Directive (Eu) 2015/2302, L 326/2),

2. Directive 2008/122/EC of the European Parliament and of the Council of 14 January 2009 on the protection of consumers in respect of certain aspects of timeshare, long-term holiday product, resale and exchange contracts,

3. Regulation (EC) No. 261/2004 of the European Parliament and of the Council of 11 February 2004 establishing common rules on compensation and assistance to passengers in the event of denied boarding and of cancellation or long delay of flights, and repealing Regulation (EEC) No 295/91.

The consumers have difficulty exercising their passenger rights, even though the EU developed a basic set of passenger rights. This is mainly due to lack of sufficient information on the EU rules and ineffective implementation thereof in some member states (European Commission, 2014). Lack of awareness of consumer rights is reflected in respondents' reluctance to file complaints. The most frequent reason for not doing so is the fear that the complaint would be rejected (ESCAPE, 2015). Knowledge is power, and if consumers know their rights, they will be more confident in their implementation. 


\section{Direct Sources of European Union Law That Pertain to Consumers of Tourism Services}

Council Directive no. 90/314/EEC of 13 June 1990 on package travel, package holidays and package tours (hereinafter referred to as the Directive on packages) (Council Directive 90/314/EEC, L 158/59) is the first binding act in the domain of consumer protection in EU tourism. The end of 2015 saw the adoption of the new Directive (EU) 2015/2302 of the European Parliament and of the Council of 25 January 2015 on package travel and linked travel arrangements, amending Regulation (EC) No 2006/2004 and Directive 2011/83/EU of the European Parliament and of the Council and repealing Council Directive 90/314/EEC. The current Directive shall be repealed on o1 July 2018 , by which time EU countries must bring their legislation into compliance with the new Directive. Since the new Directive is yet to enter into force, this paper shall present only key provisions of the current Directive on packages and indicate the direction of the new Directive. According to the Directive on packages, 'package' means the pre-arranged combination of at least two out of three individual services when sold or offered for sale at an inclusive price and when the service covers a period of more than twenty-four hours or includes overnight accommodation. The three services of which at least two must be included in order for a deal to be considered as 'package' are: a) transport; b) accommodation; c) other tourism services, accounting for a significant portion of the package.

The first protective provision of the Directive pertains to transparency. The Directive specifies that a brochure that is made available to the consumer shall indicate in a legible, comprehensible and accurate manner both the price and adequate information on the destination and the means, characteristics, and categories of transport used. The brochure should contain precise data on the accommodation, meal plan, itinerary, and data on travel documents, method of payment, and the minimum number of persons required for the package to take place.

The prices in the contract shall not be subject to revision unless the contract expressly provides the possibility of upward or downward revision. The contract must specify how the revised price is to be calculated. In that case, revision of the price and variations are allowed only for 'transportation costs, including the costs of fuel; dues, taxes or fees chargeable for certain services, such as landing taxes or embarkation or disembarkation fees at ports and airports; the exchange rates applied to the particular package'.

This Directive also ensures consumer protection through the obligation of the organizer to determine as soon as possible, prior to the departure, whether he must significantly adjust any essential terms like the price and notify the consumer without delay. Pursuant to the options specified in the Directive, the consumer may withdraw from the contract without the stipulated penalty or accept a rider to the contract, which specifies the changes and their effect on the price.

The obligation of particular importance that arises from the Directive for Member States is that 'the organizer and/or retailer party to the contract shall provide sufficient evidence of security for the refund of money paid over and for the repatriation of the consumer in the event of insolvency'. The key changes in the new Directive, which shall apply as of 1 July 2018 and which shall repeal the current Directive, pertain to defining the obligations of travel retailers and organizers regarding the notifications they must provide to travellers. On the other hand, the annex to the new Directive also contains the forms that must accompany the conclusion of each package travel contract and special protection of consumers, i.e. travellers in case of insolvency of the travel organizer. This is also confirmed in Art. 1. in the Preamble of the Directive, which states the need to adopt a new Directive. The reason that is pointed out is in particular with regard to information requirements, the liability of traders in relation to the performance of a package, and protection against the insolvency of an organizer or a retailer' (Council Directive 90/314/EEC, L 158/59).

Directive 2008/122/EC of the European Parliament and of the Council of 14 January 2009 on the protection of consumers in respect of certain aspects of timeshare, long-term holiday product, resale and exchange contracts. The Preamble of the Directive 2008/122/EC points out that since the adoption of the previous Directive 94/47/EC of the European Parliament and of the Council of 26 October 1994 timeshare has evolved and that new holiday products similar to it have appeared on the market (Directive 94/47/EC). One might say that this Directive is, more than any other, focused on informing the consumers even in the phase prior to contract conclusion. The annexes thereto contain five standard forms related to the contracts, so that all consumers in all Member States have precise data regarding the subject of the contract.

For timeshare, long-term holiday product, resale and exchange contracts, Directive 2008/122/EC allows for the right to withdraw from the contract and the period during which withdrawal is allowed, as well as prohibition of advance payments during the withdrawal period. A very specific provision of Directive $2008 / 122 / \mathrm{EC}$ is given in Art. 11. According to it, 
Member States shall ensure that, in the event the consumer exercises the right to withdraw from the contract, any ancillary exchange contracts or other ancillary contracts are automatically terminated, without any obligations to the consumer, but also credit agreements 'where the price is fully or partly covered by a credit granted to the consumer by the trader, or by a third party on the basis of an arrangement between the third party and the trader' (Directive 2008/122/ EC, L 33/10).

Regulation (EC) no 261/2004 of the European Parliament and of the Council of 11 February 2004 establishing common rules on compensation and assistance to passengers in the event of denied boarding and of cancellation or long delay of flights, and repealing Regulation (EEC) No 295/91. Regulation (EU) no. 261/2004 does not pertain solely to passengers travelling for tourism purposes but to all passengers, but considering the importance of regulating this domain for tourism and the fact that it pertains not only to passengers of scheduled flights but also passengers on non-scheduled flights, including the flights that are part of package tours, we classified it among direct sources of law in the domain of consumer protection in tourism..

The Regulation protects passengers who are denied boarding, if their flight is cancelled or delayed, namely all the passengers who are travelling. Regulation no. 261/204 aims to ensure that the number of passengers who are denied boarding to a reserved flight or whose flight is cancelled or delayed is reduced to a minimum. The first category introduced by the Regulation is 'volunteer' for abandoning one's reservation in exchange for benefits under the conditions agreed by that pas- senger and the operating air carrier. This reduces the number of dissatisfied passengers. If, however, passengers are denied boarding against their will, the air carrier shall immediately compensate them. The amount of compensation to be paid is laid down under Art. 7, depending on the length of the flight for which boarding is prevented. The compensation is decreased by $50 \%$ if the passengers accepted the offered re-routing and if the arrival time does not exceed the scheduled arrival time of the original flight. However, passengers may decide whether they wish to reach the desired destination through re-routing or to be reimbursed. In case of the latter, reimbursements are paid within seven days, namely 'the full cost of the ticket at the price at which it was bought, for the part or parts of the journey not made, and for the part or parts already made if the flight is no longer serving any purpose in relation to the passenger's original travel plan' (Regulation (EC) No 261/2004, L 46/1).

Pursuant to this Regulation, passengers have the right to a care, which includes meals and refreshments in reasonable relation to the waiting time, hotel accommodation when staying for a night or more is necessary and the transport between the airport and the place of accommodation (hotel or other). Furthermore, passengers have the right to two free phone calls, fax messages or emails.

The Regulation specifies that, if an air carrier transfers a passenger to a class higher than the one for which the ticket was paid, it may not seek any supplementary payment. However, if a passenger is placed in a lower class, the air carrier shall reimburse said passenger in the amount of $30-70 \%$, depending on the length of the flight.

\section{Consumer protection in tourism industry}

Contemporary tourists are becoming more critical, less loyal, seeking value for money, not necessarily lowest prices. Educated, informed and confident tourists are helped to reduce poor behavior by suppliers of goods and services, reducing hidden risks, either from inferior goods and services or from rogue suppliers. When problems arise, empowered tourists are more able to seek redress and avoid further detriment. More confident and informed tourists can invigorate competition between suppliers, promoting product and service quality, efficiency and innovation (Greenwood \& Dwyer, 2014).

Some authors were more concerned with general consumer protection. Ene (2012) investigated consumer protection in Bulgaria. She stated that the Bulgarian Law on Tourism (last amended in 2010) mostly focuses on providing protection for users of tourist products/packages and establishing the rights and obligations of consumers in this field. Greenwood and Dwyer (2014) researched challenges to consumer protection legislation in Australia. In one chapter of the book Consumer Law and Socioeconomic Development, Marques and Wei (2017) give an overview of consumer protection in the global context.

Rights and regulations can shape the possibilities for travel and tourism as importantly, they can also restrict them too (Hall, 2008). Consumer protection measures enhance destination competitiveness, helping to minimize tourist dissatisfaction through more transparent and efficient market operations, while creating and maintaining customer loyalty, and consumer confidence. Transparency in policy making, enshrined in legislation and legal precedent, is an important component of a fair and equitable legal sys- 
tem. If there is a perception by tourists that the legal system is unfair then it will be misused. The legal system is not foolproof, but as society evolves in concert with changing values, technology and access so does the law, albeit slowly in some countries (Greenwood \& Dwyer, 2015).

On the basis of fundamental theories of law and economics, with the help of tools of game theory, Tan et al. (2017) investigated the protection of tourist consumers' rights and interests. Results show that the costs of a suit for protection of tourist consumers' rights and interests are positively correlated with the chance of infringement of tourist companies, while negatively correlated with the chance for tourist consumers to file a suit for protection.

Petrović and Milićević (2017) investigated the impact of consumer protection on destination competitiveness in the European Union. The analysis indicated that the European Union member states that record the highest consumer confidence and the low- est level of illicit commercial practices also record the highest competitiveness as a tourism destination.

The Ministry of Agriculture, Trade, Forestry and Water Management is since August 2011 conducting the EU-funded project Strengthening Consumer Protection in Serbia. The overall objective of the survey was to provide information about consumer protection awareness and the 2010 Law on Consumer Protection among Serbian citizens. Results of the survey have shown that consumers in Serbia are generally insufficiently informed about consumer rights, their legal regulation and the law enforcement mechanisms. Although they mostly know at least one consumer right, their knowledge is usually narrow and vague (MASMI, 2012).

Based on a review of the literature regarding consumer protection in tourism industry, the main hypotheses can be drawn:

H1: Serbian consumers are generally poorly informed on the rights of consumers of tourism services and legislation that governs those rights.

\section{Methodology}

The quantitative research was carried out on a convenience sample of 527 respondents from the Republic of Serbia. The survey was conducted via emails and faceto-face interviews in the period 15 October-15 December 2017. The research included five interviewers. The questionnaires were emailed to tourist agencies, tourist organizations, and students of tourism and hotel management (former and current students whose email addresses are in the database) at the Department of Geography, Tourism and Hotel Management, Faculty of Sciences, Novi Sad. Another 147 questionnaires were completed through face-to-face interviews. A total of 1,00o questionnaires were distributed, of which $52.7 \%$ were returned.

The questionnaire is comprised of two parts: sociodemographic questions (7 questions) and the main part focused on the awareness of the protection of consumers of tourism services (30 questions, of which 1 is an open-type question). The research used a modified and adjusted questionnaire for studying con- sumer awareness (MASMI, 2012). The main portion consists of four sections: 1) Awareness of the rights of consumers of tourism services, 2) Level of certainty regarding the rights of consumers of tourism services, 3) Sources of information on the rights of consumers of tourism services, 4) Institutions and organizations dealing with protection of consumers of tourism services.

The main objective of the research is to provide information on Serbian citizens' awareness of the protection of consumers of tourism services in EU countries. Special objectives of the research are to provide answers to the following questions: 1 ) Which rights of consumers of tourism services are known to the respondents? 2) On which matters is consumer awareness at its lowest/highest? 3) Which information sources do respondents recognize as being readily available/credible/appealing? 4) Which institutions dealing with problems of consumers are recognized as readily available/credible/appealing?

\section{Results of the Research}

\section{Description of the Sample}

In relation to the gender structure, the sample had more female respondents (53.1\%); while in relation to occupation and education, the sample included more employed persons (61.9\%) with high school de- gree $(53.3 \%)$. In relation to the region, the most numerous were respondents from Vojvodina province $(45.9 \%)$, while more than half of the respondents from the sample have monthly income between 201$400 €$. 
Table 2. Socio-demographic data on the respondents $(N=527)$

\begin{tabular}{|l|r|r|l|r|r|}
\hline Variables & Sample size & \multicolumn{1}{l|}{$\%$} & Variables & Sample size & $\%$ \\
\hline Gender & 247 & 46.9 & $\leq 200 €$ & & \\
\hline male & 280 & 53.1 & $201-400 €$ & 35 & 6.6 \\
\hline female & 141 & 26.8 & $601-1000 €$ & 285 & 54.1 \\
\hline Age & 149 & 28.3 & $1001 € \geq$ & 83 & 15,7 \\
\hline $21-30$ & 132 & 25.0 & Region & 97 & 18.4 \\
\hline $31-40$ & 57 & 10.8 & Vojvodina & 27 & 5.1 \\
\hline $41-50$ & 48 & 9.1 & Belgrade & 242 & 45.9 \\
\hline $51-60$ & & & Central Serbia & 127 & 24.1 \\
\hline $61 \geq$ & 281 & 53.3 & Occupation & 158 & 30.0 \\
\hline Education & 61 & 116 & Student & & \\
\hline Secondary education & 89 & 16.9 & Employed & 326 & 61.9 \\
\hline College & 58 & 11.0 & Retired & 56 & 10.6 \\
\hline Higher education & 38 & 7.2 & Unemployed & 33 & 6.3 \\
\hline Master's degree & & & & & \\
\hline Doctor's degree & & & $401-600 €$ & & \\
\hline
\end{tabular}

\section{Results of Descriptive Statistical Analysis}

The analysis of answers to the open-type question Specify which rights of consumers of tourism services in EU countries you know of, has revealed that the right to complain about a package is the right that citizens are generally aware of $(67 \%$ of the respondents have specified this right). Accurate information on the price of the package, residence and airport fees, transportation, travel conditions, characteristics of accommodation, periods and conditions for acquiring travel documents and visas, travel insurance, etc. are also examples of what $52 \%$ of the respondents perceive as their consumer rights. It is known that purchase package tours greatly depend on how much information can be obtained from tour operators (Gursoy \& McCleary, 2004; Xiang \& Gretzel, 2010). In order to purchase with confidence, consumers need easy access to precise information and professional advice (Dinu et al., 2010). The right to cancel the travel is known to $42 \%$ of the respondents, while the rights that tour- ists have in case of delayed flights or loss of luggage are known to $39 \%$ of the respondents. Citizens over 61 are the least aware of consumer rights $-32 \%$ of them cannot specify any of the rights. Those under 30 are somewhat more aware, whereas middle-aged citizens are aware the most $(86 \%$ of them specified at least one right). Education can also be used as an indicator of awareness of consumer rights; those with higher education tend to know what rights they have as consumers of tourism services.

It has been shown that $85.8 \%$ of the respondents believe that Serbia has the Consumer Protection Law; however, $82.4 \%$ do not know what their rights are when travelling to EU countries, or that there are eight EU directives and regulations that directly or indirectly govern the protection of consumer rights in tourism (91.1\%). Where protection of consumer rights is concerned, the respondents trust consumer protection associations, but lack information on those associations (web pages of consumer protection associations

Table 3. Awareness of the rights of consumers of tourism services

\begin{tabular}{|c|c|c|c|c|}
\hline \multirow{2}{*}{ Variables } & \multicolumn{2}{|l|}{ Yes } & \multicolumn{2}{|l|}{ No } \\
\hline & Frequency & $\%$ & Frequency & $\%$ \\
\hline $\begin{array}{l}\text { In some countries, consumer rights are regulated under consumer protection laws. } \\
\text { In your opinion, is there such a law in Serbia? }\end{array}$ & 452 & 85.8 & 75 & 14.2 \\
\hline $\begin{array}{l}\text { Are you aware that there are eight EU directives and regulations that directly or } \\
\text { indirectly pertain to the protection of consumer rights in tourism? }\end{array}$ & 47 & 8.9 & 480 & 91.1 \\
\hline Are you aware of your rights when travelling to EU countries? & 93 & 17.6 & 434 & 82.4 \\
\hline Do you believe that consumer protection associations could help protect your rights? & 439 & 83.3 & 88 & 16.7 \\
\hline Do you follow web pages of consumer protection associations? & 45 & 8.5 & 482 & 91.5 \\
\hline Are you a member of any consumer protection association? & 5 & 0.9 & 522 & 99.1 \\
\hline If not, do you plan on becoming one? & 176 & 33.4 & 346 & 65.7 \\
\hline
\end{tabular}


are followed by $8.5 \%$, whereas only $0.9 \%$ are members of such associations), although there are 27 consumer protection organizations registered in Serbia (Internet 2). Consumer quality in Serbia is continuously evolving, but the number of organizations do not guarantee quality, organization and coordination of associations and their activities in consumer protection. The relatively large number of organizations and their insufficient coordination are the reasons why their overall impact is low and mostly related to units of local self-governments (Veljković, 2013).

Using the results on the level of certainty regarding the rights of consumers of tourism services (Table 4) and the t-test for paired samples, the authors determined that there is statistically significant difference between the attitudes towards Serbian and EU legislation; namely, the respondents believe that consumers of tourism services in the EU enjoy better legal protection on all matters.

Two thirds of the respondents are not aware that a consumer in Serbia who concludes a timeshare or similar contract may withdraw from the contract after it was concluded and that there is a period during which withdrawal is allowed. Furthermore, the citizens also lack awareness of the right to transfer the reservation to a person who meets all the requirements pertaining to the package, provided that before departure the buyer (consumer) gave the tour operator or agency (retailer) a valid reason for cancelling the travel. Average scores under 3.5, which indicate respondents' uncertainty regarding the existence of the rights of consumers of tourism services, were also recorded for questions pertaining to consumer rights in the event the provided quality of transport or accommodation is subpar, as well as the rights they have when being denied boarding. The respondents are certain that all of the aforementioned items are more prevalent in the legislation of EU countries than in Serbia. Also, with regard to EU legislation, they are least certain about the rights of consumers of tourism services that pertain to the transfer of the package to another person and the right to withdrawn from timeshare and other similar contracts. The highest level of certainty was shown regarding the right to information

Table 4. Level of certainty regarding the rights of consumers of tourism services

\begin{tabular}{|c|c|c|c|c|c|}
\hline \multirow{2}{*}{$\begin{array}{l}\text { Specify on a scale from } 1 \text { to } 5 \text { how certain you are that } \\
\text { these rights are (not) to be found in: } \\
\text { A) Serbian legislation B) EU legislation } \\
\text { (Use } 1 \text { to mark 'I am certain that this right is not regulated } \\
\text { under law' and } 5 \text { to mark 'I am certain that this right is } \\
\text { regulated under law') }\end{array}$} & \multicolumn{2}{|c|}{ A) Serbian legislation } & \multicolumn{2}{|c|}{ B) EU legislation } & \multirow[t]{2}{*}{ t-test } \\
\hline & Mean & \begin{tabular}{c|} 
Std. \\
Deviation
\end{tabular} & Mean & \begin{tabular}{c|} 
Std. \\
Deviation
\end{tabular} & \\
\hline $\begin{array}{l}\text { The organizer and/or retailer (agency) must provide the con- } \\
\text { sumer, in writing or any other appropriate form, the general } \\
\text { data on passports and visas for citizens of Member States or } \\
\text { the states in question, particularly on the period for acquir- } \\
\text { ing them, as well as data on medical formalities necessary } \\
\text { for the travel and subsistence. }\end{array}$ & 4.0911 & 1.04974 & 4.5066 & 0.7722 & $-14.471^{*}$ \\
\hline $\begin{array}{l}\text { If a consumer pays for a package through a travel agen- } \\
\text { cy, and it happens that the hotel accommodation specified } \\
\text { in the package is unavailable, the travel agency is obliged to } \\
\text { provide other accommodation without any additional costs } \\
\text { to the consumer. }\end{array}$ & 3.8748 & 1.1665 & 4.4839 & 0.6943 & $-18.355^{*}$ \\
\hline $\begin{array}{l}\text { If a consumer receives lower quality of transport or accom- } \\
\text { modation than that arranged when purchasing the travel } \\
\text { package, he/she is entitled to seek from the travel agency to } \\
\text { reduce the price of the package or reimburse him/her. }\end{array}$ & 3.2239 & 1.5474 & 4.1139 & 1.0236 & $-13.944^{*}$ \\
\hline $\begin{array}{l}\text { If an airplane passenger is denied boarding against his/her will, } \\
\text { the air carrier is obliged to immediately reimburse him/her. }\end{array}$ & 3.1176 & 1.2925 & 3.7059 & 1.1727 & $-9.536^{*}$ \\
\hline $\begin{array}{l}\text { If a consumer is prevented from realizing the package, he/ } \\
\text { she may transfer his/her reservation to a person who meets } \\
\text { all the requirements pertaining to the package, provided that } \\
\text { before departure the consumer gave the tour operator or } \\
\text { agency (retailer) a valid reason for cancelling the travel. }\end{array}$ & 3.0816 & 1.0514 & 3.5009 & 1.1148 & $-12.095^{*}$ \\
\hline $\begin{array}{l}\text { A consumer in a timeshare or other similar contract is allowed } \\
\text { to withdraw from the contract after it was concluded; the pe- } \\
\text { riod during which withdrawal is allowed is prescribed; no ad- } \\
\text { vance payments are allowed during the period for withdrawal. }\end{array}$ & 3.0000 & 1.4787 & 3.6717 & 1.3553 & $-11.617^{*}$ \\
\hline
\end{tabular}


Table 5. Opinion regarding availability, appeal and credibility of information sources

\begin{tabular}{|l|r|r|r|r|r|r|}
\hline On a scale from: 1 - 'Not in the least' to 5 - 'Completely', & \multicolumn{2}{|c|}{ Availability } & \multicolumn{3}{|c|}{ Appeal } & \multicolumn{2}{|c|}{ Credibility } \\
\cline { 4 - 7 } $\begin{array}{l}\text { specify for each source of information on the protection of } \\
\text { consumer rights how available it is to you, how appealing it } \\
\text { is, and how credible you find it }\end{array}$ & Mean & Std.dev. & Mean & Std.dev. & Mean & Std.dev. \\
\hline Television & 3.9564 & 1.3413 & 3.9184 & 1.0912 & 3.3454 & 1.0720 \\
\hline Relatives, friends, acquaintances, colleagues ... & 3.6812 & 1.2569 & 3.6110 & 1.1839 & 3.4991 & 1.1367 \\
\hline Radio & 3.1082 & 1.2333 & 3.1689 & 1.1045 & 2.7970 & 0.9897 \\
\hline Newspapers (daily and periodicals) & 3.6983 & 1.1909 & 3.5389 & 1.0382 & 3.0968 & 1.0207 \\
\hline Consumer & 3.5313 & 1.1229 & 3.3795 & 1.1117 & 3.4858 & 1.1969 \\
\hline Internet & 4.4668 & 0.8926 & 4.6622 & 0.8693 & 2.8975 & 0.9877 \\
\hline Call Centre 0800 103 104 & 3.0721 & 1.2855 & 3.2638 & 0.9256 & 3.5465 & 1.2383 \\
\hline Prom promotional materials (flyers, posters, brochures, etc.) & 2.8634 & 1.2369 & 3.3017 & 0.8932 & 3.2163 & 0.9762 \\
\hline Organizations dealing with protection of consumer rights & 2.5104 & 0.8383 & 3.1252 & 1.1461 & 3.4516 & 1.1290 \\
\hline Organized discussions, lectures, workshops, or training seminars & 2.2543 & 0.9865 & 2.7306 & 1.1748 & 3.6736 & 1.1301 \\
\hline
\end{tabular}

on passports, visas, and medical formalities necessary for travel and subsistence, and consumer rights in the event when accommodation facilities are overbooked.

When evaluating different sources of information on consumer rights, the Internet is marked as being the most available information source and also the most appealing. As an information source, the Internet is more appealing to the respondents from Vojvodina province than those from Central Serbia. Television as an information source also received high scores for availability and appeal. The respondents gave high scores to availability and appeal of information received through newspapers, friends, and relatives.

The least available and the least appealing information sources are, according to the respondents, organized discussions, lectures, workshops, or training seminars and organizations dealing with protection of consumer rights. This poses a significant barrier for consumers that should be addressed further since these information sources are considered as most reliable. The respondents evaluated the radio and the Internet as least reliable.

When evaluating different organizations that deal with matters of consumer protection, it is apparent that the assessment of availability is greatly associated with the appeal and credibility of the source. Courts and market inspectorates are seen as most readily available, most appealing and most credible organizations dealing with protection of consumer rights. Unlike citizens from Central Serbia, the citizens from Vojvodina and Belgrade believe that courts and market inspectorates are more available. Regional advisory centres for consumers and chambers of commerce are considered to be least available and least appealing organizations that deal with matters of consumers. In the overall, all organizations received relatively low scores, with values exceeding the average score of 3.5 only with regard to one item, credibility of courts (3.6546).

Table 6. Opinion regarding availability, appeal and credibility of institutions dealing with matters of protection of consumer rights

\begin{tabular}{|c|c|c|c|c|c|c|}
\hline \multirow{2}{*}{$\begin{array}{l}\text { Assess the availability, appeal and credibility of } \\
\text { organizations and institutions dealing with matters of } \\
\text { consumer protection. } \\
\text { Score them on a scale from } 1 \text { - 'Not in the least' to } 5 \text { - } \\
\text { 'Completely'. }\end{array}$} & \multicolumn{2}{|c|}{ Availability } & \multicolumn{2}{|c|}{ Appeal } & \multicolumn{2}{|c|}{ Credibility } \\
\hline & Mean & Std.dev. & Mean & Std.dev. & Mean & Std.dev. \\
\hline Courts & 3.4915 & .92464 & 3.4137 & 1.0571 & 3.6546 & 1.0029 \\
\hline Market inspectorates & 2.9355 & 1.2113 & 3.0645 & 0.9308 & 3.3074 & 0.9374 \\
\hline Chambers of commerce & 2.7951 & 1.08906 & 2.8880 & 1.1423 & 3.1423 & 1.1959 \\
\hline Regional advisory centres for consumers & 2.3264 & .86752 & 2.8501 & 0.8990 & 3.1784 & 1.0584 \\
\hline
\end{tabular}




\section{Conclusion}

Consumer protection in EU tourism is regulated under a number of regulations that pertain to this domain either directly or indirectly. Standardization in this area has increased the legal security of tourists who are vacationing in the EU or using services of European business entities from this domain. European regulations in the domain of consumer protection in tourism lack uniform terminology, particularly with regard to the term's 'consumer', 'consumer in tourism', and 'passenger'. More so in practice than in theory, there is a lack of understanding of the relationship between these terms concerning their subjectivism regarding protection in the tourism services market. The current directives and regulations from this domain had been adopted and changed based on the need for unhindered use of services on the territory of the entire EU by both tourists from Member States and those coming from outside the EU. The matter of adequate implementation of directives and regulations in domestic legislations, and even more so in the practice, should be addressed further. Particular attention needs to be paid to the so called 'grey zone' in the domain of tourism, since it not only represents a fiscal problem but also affects the exercise consumer rights.

The results of the research have shown that Serbian consumers are generally poorly informed on the rights of consumers of tourism services and legislation that governs those rights. Although most respondents are able to specify at least one consumer right, their knowledge of this domain is, for the most part, limited and vague. Application of t-test for paired samples has shown that there are statistically significant differences between the attitudes towards Serbian and EU legislation, namely that the respondents believe that consumers of tourism services in the EU enjoy better legal protection.

For Serbian citizens, the central point in understanding the concept of the rights of consumers of tourism services is the right to complain. The right to accurate information on the price of the package, residence and airport fees, transportation, travel conditions, and other matters is also well known. Citizens over 61 are the least aware of consumer rights, whereas middle-aged citizens are aware the most. Education is another indicator of awareness of consumer rights; those with higher education tend to be more aware of the rights of consumers of tourism services.

The Internet and television are the main communication channels for Serbian citizens, seeing as they are most readily available and appealing sources of information. However, in addition to the radio, the Internet received the lowest scores for the credibility of information. Newspapers, friends and relatives received high scores for availability and appeal.

Most of the respondents do not see themselves as becoming members of consumer protection organizations. Middle-aged citizens and those with higher education often responded that they could become members of consumer protection organizations.

In order to raise Serbian citizens' awareness of the rights of consumers of tourism services, an intensive and comprehensive information campaign on their rights should be conducted. The Internet and television should be used as main communication channels involved in the campaign for raising awareness of consumer rights. Television is a universally accessible and popular means of communication since it reaches all demographic groups. Newspapers and specialized journals may be used as ancillary means in spreading the information on consumer rights. Involvement of consumer protection organizations in the process of spreading the information on consumer rights may have a positive effect; regardless of how low their scores in the domain of availability are, the respondents consider them as being the most credible sources of information on consumer rights.

Considering that research results indicate low level of citizens' awareness regarding the rights of consumers of tourism services, it is evident that this matter should be given greater importance by involving experts who would educate consumers through various courses and workshops. Future research may focus on comparing the levels of consumer awareness in the neighbouring countries.

\section{Acknowledgements}

This study resulted as a part of National project of Ministry of Science and Technological Development No. 47024 and of the project No. 142-451-2356/2018-03 funded by the Provincial Secretariat for Science and Technological Development of the Vojvodina Province, Serbia. 


\section{References}

Council Directive (90/314/EEC). Council Directive on package travel, package holidays and package tours, L 158/59 (Available at: http://eur-lex.europa.eu/LexUriServ/LexUriServ.do?uri=CELEX:3199oLo314:en :HTML)

Dinu, V., Marchevski, I., Dobrescu, E. \& Petrescu, R.M. (2010). Education and training needs in the field of consumer protection in the Lower Danube Region. Amfiteatru Economic, 12(4), 709-734.

Directive $94 / 47 / \mathrm{EC}$ on the protection of purchasers in respect of certain aspects of contracts relating to the purchase of the right to use immovable properties on a timeshare basis; L 280, 29/10/1994 P. 0083 - 0087 (Available at: http://eur-lex.europa.eu/LexUriServ/LexUriServ.do?uri=CELEX:31994Loo47:E $\mathrm{N}: H T M L, 20.12 .2017$.)

Directive 2008/122/EC on the protection of consumers in respect of certain aspects of timeshare, longterm holiday product, resale and exchange, $\mathrm{L} 33 / 10$ (Available at: http://eur-lex.europa.eu/legal-content/EN/TXT/PDF/?uri=CELEX:32008Lo122\&fro $\mathrm{m}=\mathrm{en}$ )

Directive 2011/83/EU on consumer rights, amending Council Directive 93/13/EEC and Directive 1999/44/ EC of the European Parliament and of the Council and repealing Council Directive 85/577/EEC and Directive 97/7/EC of the European Parliament and of the Council, L 304/64 (Available at: http://eurlex.europa.eu/LexUriServ/LexUriServ.do?uri=OJ:L :2011:304:0064:0088:en:PDF)

Directive (EU) 2015/2302 on package travel and linked travel arrangements, amending Regulation (EC) No 2006/2004 and Directive 2011/83/EU of the European Parliament and of the Council and repealing Council Directive 90/314/EEC; L 326/2 (Available at: http://eur-lex.europa.eu/legal-content/EN/ TXT/PDF/?uri=CELEX:32015L2302\&from=EN)

Ene, C. (2012). Consumer Protection in Bulgaria: EU Challenges. Economics of Agriculture 59(2), 253-265.

ESCAPE (2015). Report on Senior Tourists needs and demands (Available at: http://www.age-platform. eu/images/ESCAPE_Needs_and_expectations_ FINAL.pdf; 29.12.2017)

European Commision (2013). COM (2013/0513 final) Communication from the Commission to the European Parliament, the Council, the European Economic and Social Committee and the Committee of the Regions Bringing the EU Package Travel Rules into the Digital Age (Available at: https://eurlex.europa.eu/legal-content/EN/TXT/HTML/?uri $=$ CELEX:52013DCo513\&from $=$ EN; 15.02.2018).
European Commission (2014). Report on Consumer Policy, January 2012 - December 2013 (Available at: https://ec.europa.eu/info/sites/info/files/consumer_ policy_report_2014.pdf; 08.12.2017)

Gharibeh, A. (2011). Tourism rights and the foreign tourists. Public Law Quarterly 11, 205-211.

Greenwood, V., \& Dwyer, L. (2014). Challenges to Consumer Protection Legislation in Tourism Contexts. Journal of Tourism Consumption and Practice 6(2), 1-22.

Greenwood, V. A., \& Dwyer, L. (2015). Consumer protection legislation: A neglected determinant of destination competitiveness? Journal of Hospitality and Tourism Management 24, 1-8.

Gursoy, D. \& McCleary, K. W. (2004). An Integrative Model of Tourists' Information Search Behavior. Annals of Tourism Research 31(2), 353-73. http:// dx.doi.org/10.1016/j.annals.2003.12.004

Hall, C. M. (2008). Tourism planning: Policies, processes and relationships (2nd Edition). Pearson Education.

Marques, L., \& Wei., D. (Eds.) (2017). Consumer Law and Socioeconomic Development. Springer International Publishing

MASMI (2012). Istraživanje o nivou svesti o zaštiti potrošača i zakonu o zaštiti potrošača u Srbiji. Beograd. [Research on the level of consumer protection awareness and the Consumer Protection Law in Serbia] (In Serbian with English summary) (Available at: http://www.zapotrosace.rs/CMS/ download/poznavanje_prava_potrosaca_finalni_ izvestaj.pdf)

Petrović, J., \& Milićević, S. (2017). Consumer Protection as a Factor of Destination Competitiveness in the European Union. Amfiteatru Economic Journal 19(45), 432-446.

Regulation (EC) No 261/2004 Establishing common rules on compensation and assistance to passengers in the event of denied boarding and of cancellation or long delay of flights, and repealing Regulation (EEC) No 295/91, L 46/1 (Available at: http://eurlex.europa.eu/resource.html?uri=cellar:439cd3a7$\mathrm{fd}_{3} \mathrm{c}-4 \mathrm{da} 7-8 \mathrm{bf} 4-\mathrm{b}$ of $60600 \mathrm{c} 1 \mathrm{~d} 6.0004 .02 /$ DOC_1\&format=PDF)

SORS/Statistical Office of the Republic of Serbia. (2018). Statistical yearbook of the Republic of Serbia, Belgrade (Available at: http://publikacije.stat.gov.rs/ G2018/Pdf/G20182051.pdf)

Tan, X., Chen, Z., Guan, B., Yang, C., \& Wu, G. (2017). Game theory analysis of protection of tourist consumers' rights and interests at lawsuit angle. Jour- 
nal of Discrete Mathematical Sciences and Cryptography 20(4), 885-897.

UNWTO (2018). European Union Tourism Trends, Madrid; https://doi.org/10.18111/9789284419470.

Veljković, S. (2013). Zaštita potrošača u Republici Srbiji u procesu pridruživanja Evropskoj Uniji [Consumer protection in the Republic of Serbia in the process of joining the European Union.]. Marketing, 44 (1), 49-74. (in Serbian with English summary)

World Travel \& Tourism Council (2018). Travel \& Tourism. Economic Impact 2018 - Serbia, (retrieved from https://www.wttc.org/-/media/files/reports/ economic-impact-research/countries-2018/serbia2018.pdf; 09.03.2019.)

Xiang, Z., \& Gretzel, U. (2010). Role of Social Media in Online Travel Information Search. Tourism Man- agement 31(2), 179-88. http://dx.doi.org/10.1016/j. tourman.2009.02.016

Živković, R. (2013). Ponašanje i zaštita potrošača $u$ turizmu [Behavior and Consumer Protection in Tourism], Fakultet za turistički i hotelijerski menadžment, Beograd: Univerzitet Singidunum. (in Serbian with English summary)

Internet 1: http://www.novosti.rs/vesti/turizam.9o. html:765837-Za-pet-godina---65-odsto-vise-stranaca-u-Srbiji (o9.03.2019.)

Internet 2: http://www.zastitapotrosaca.gov.rs/evidentirana-udruzenja.php (15.02.2018.) 